\title{
SYNCHRONIZING DEDUCTIBLE TAXES AND TAXABLE INCOME
}

\author{
Robert Hanes Grax*
}

$7 \mathrm{HE}$ fundamental importance of correct timing in the computation of annual income is generally recognized. Any business activity continuing over a period longer than that under observation involves a flow of revenue and a flow of expense which must be carefully matched. ${ }^{x}$ If this is not done, provisional estimates ${ }^{2}$ may give a highly distorted picture of the operations of an enterprise. ${ }^{3}$ Fortunately, in calculating periodic gain a considerable part of the expense and revenue is so closely related to the period for which the estimate is made that there is, no serious dispute as to its proper allocation. The difficulties of matching are caused by the items which are also identifiable with preceding or subsequent periods or which are not readily identifiable with any particular time. ${ }^{4}$ In part these difficulties may be overcome by using accepted accounting guides to allocate revenue and expense to the appropriate year. However, there remains a broad area of doubt and uncertainty where the guides or their application are controverted; consequently estimates of annual income may vary measurably even though made by persons of experienced judgment. ${ }^{5}$

Yet in spite of the wide variations in income estimates the need for timely reports has compelled more frequent sampling than that afforded by the annual statement. ${ }^{6}$ In addition, even the annual report is being

* Assistant Professor of Law, University of Louisville.

× See Paton and Littleton, An Introduction to Corporate Accounting Standards 5 (I940).

$z$ "All measures of income for periods less than the total lapse of time during a relationship or less than the duration of an enterprise are approximate indexes only." Canning, The Economics of Accountancy I24 (I929).

3 Simons, Personal Income Taxation 50 (I938).

4 See Sanders, Hatfield, and Moore, A Statement of Accounting Principles 25-26 (r938).

5 Blough, Accounting Principles Interpreted in Light of Recent Developments, $12 \mathrm{~J}$. of Bus. of Univ. Chi. 265 (I939); Scott, Responsibilities of Accountants in a Changing Economy, I4 Accounting Rev. 396, 400, 40I (r939); Berle, Accounting and the Law, $65 \mathrm{~J}$. of Accountancy 368 (1938); Sanders, The Development of Accounting Principles, ro Accounting Rev. 100 (r935); May, Uniformity in Accounting, I7 Harv. Bus. Rev. I (1938); Greer, What Are Accepted Principles of Accounting?, $x_{3}$ Accounting Rev. 25 (1938).

${ }^{6}$ See Porter and Fiske, Accounting I4I (1935); Paton, Essentials of Accounting 356 (r938). 
used for purposes other than those for which it was originally intended.7 The income tax, of course, furnishes but one example of this practice. ${ }^{8} \mathrm{Un}$ like the uses originally made of such reports, their use as the basis for income tax assessment gives direct and tangible effect to conclusions which are admittedly nothing more than estimates-conclusions which frequently are not taken at their face value, but which are used merely in connection with other significant evidence. ${ }^{x 0}$ It is one thing to compute earnings for the purpose of indicating to creditors, owners, and managers the general progress of a business; it is quite another to make the same estimate and then be compelled to pay a large part of it to the Federal Government. Certainly the customary accuracies of matching which are deemed both elementary and essential when making estimates for business purposes should be necessary a fortiori when computing taxable income.

In the zone where individual opinion plays such a large part (as, for example, where contingency reserves are involved) it is only to be expected that, when providing for the collection of the income tax, the Government will insist upon practices which will protect its revenue. ${ }^{\text {II }}$

7 For some of the law-accounting problems of one agency alone see Sanders, Accounting Aspects of the Securities Act, 4 Law \& Contemp. Prob. I9I (1937); Kaplan and Reaugh, Accounting, Reports to Stockholders, and the SEC, 48 Yale I. J. 935 (r939); MacChesney, The Securities and Exchange Commission's Development of Accounting Standards, 26 Calif. L. Rev. 349 (1938); Securities Legislation-Accounting Practice and the Securities Act of 1933, 37 Mich. L. Rev. 288 (1938); Accounting Principles and Auditing Responsibilities Established under the Securities Acts, 33 Ill. L. Rev. 820 (1939); Selected Problems in Valuing Assets under the Securities Act, 25 Iowa L. Rev. I05 (1939); Greidinger, What Has the S.E.C. to Offer the Tax Accountant?, I8 Taxes 477 (1940); see also Kripke, Accountants' Financial Statement and Fact-finding in the Law of Corporate Regulation, 5o Yale L. J. Ir80 (r94r).

${ }^{8}$ It has been said, however, that the adoption of the Sixteenth Amendment was "the greatest forward impulse the science and the profession of accountancy has ever received in this country." Meyer, The Income Tax-Accounting Aspects, 3 Accounting Rev. I8 (I928). While there has been an unfortunate tendency to keep books in conformity with the requirements of the Treasury Department instead of shaping accounting practices to the needs of business, Isaacs, Review of Graham and Katz, Accounting in Law Practice, 28 IIl. L. Rev. 440 (1933); Blough, op. cit. supra note 5, at 269-70, there has been, nevertheless, a decided improvement in accounting practice which is directly attributable to income tax legislation, Magill, Taxable Income I9 (I936); Pearce, Income Tax Fundamentals iv (1937); Paton, op. cit. supra note 6, at Ir; Davies, The Changing Objectives of Accounting, 4 Accounting Rev. 94, I03-4 (I929); Husband, Accounting Postulates, I2 Accounting Rev. 386 (1937).

9 "Accurate net income is the result of good guessing." Montgomery, Accounting and the Concept of Income, in Magill, Lectures on Taxation 39, 42 (I932).

so See Graham and Katz, Accounting in Law Practice 334-36 (2d ed. 1938).

Ix "Some of these differences are due to special tax considerations and are necessary even if in conflict with sound accounting usages. Others are designed to protect the government against tricks of tax avoidance and hence appear to be justified." Gilman, Accounting Concepts of Profit I7 (I939). 
But where accounting guides supply adequate safeguards it is difficult to understand the need for rulings which, instead of accepting orthodox techniques, compel the taxpayer to distort his annual income. This is particularly true with respect to the deduction of taxes from gross income, ${ }^{12}$ a deduction which, in many cases, is easily allocable to a specific period of time.

\section{I}

The first federal income tax statute, the act of I86r, permitted the deduction of taxes which were "assessed." I3 This ambiguous allowance caused no difficulty since the tax was not collected. However, a problem of interpretation was presented by the acts of 1862 and 1864 , which allowed the deduction of "lawfully assessed" taxes by the person who "actually" paid "the same." ${ }^{4}$ Influenced by these two limitations, the statute was apparently interpreted to permit only the allowance of those taxes which were both assessed and paid within the year claimed. ${ }^{\mathrm{Is}}$ Any hardships caused by this restriction were relieved in 1865 when the statute was amended to permit the deduction of taxes "paid within the year."I6 A tax which was assessed or which became due and payable in one year and was not actually paid until a subsequent year could be deducted only in the later year. ${ }^{x 7}$ The cash disbursement basis for the deduction of taxes was also included in the act of $1870^{18}$ and the ineffectual act of $1894 .{ }^{x 9}$

During the Civil War era the use of the cash basis for income tax purposes may have been adequate for ordinary business. Small-scale production and modest capital investments did not call for extensive accounting records. But with the revolutionary growth of industry, commerce, and finance which followed this era, legislation which borrowed the primitive

12 Int. Rev. Code $\S 23$ (c), 53 Stat. I2 (I939), 26 U.S.C.A. $\$ 23$ (c) (I940).

${ }_{33}$ "In estimating said income, all national, state, or local taxes assessed upon the property from which the income is derived, shall be first deducted." I2 Stat. 309 , at $\$ 49$ (I863).

$x_{4}$ "In estimating .... annual gain . . . all .... taxes, lawfully assessed .... shall be first deducted from the .... income of the person or persons who actually pay the same." I2 Stat. 473, at $\$ 9$ I (I863); I3 Stat. 28 I, at $\$$ II 7 (I866).

${ }^{15}$ See the tax return reprinted in Estee, Excise Tax Law 304 (r863), which reads, in part, as follows: "4. Other national, state, and local taxes assessed and paid for the year 1862 and not elsewhere included." In the act of 1864 the words "within the year" were added after "lawfully assessed." $x_{3}$ Stat. $28 \mathrm{I}$, at § II7 (I866).

16 "All taxes paid within the year shall be deducted from the ... . income of the person who has actually paid the same." I3 Stat. 479 (I866).

${ }^{17}$ See T. D., May 18, 1867, and T. D., January, 1868, in Digest of Internal Revenue Decisions I864-I898, at I28 (I906); 7 I.R.R. 60 in Bump, Internal Revenue Laws 292 (I870). ${ }^{18}$ I6 Stat 258 , at $\S 9(187 \mathrm{I})$.

1928 Stat. 553 , at $\S 28,556$, at $\S 32$ (1895). 
income concept of a simpler economy proved hopelessly inadequate even in I909. Although accountancy in the United States was still in its infancy, ${ }^{20}$ the accrual method of computing annual profits had been adopted to an extent which made it virtually impossible for many corporations to comply with the Corporation Franchise Tax Act which required the use of the cash basis. ${ }^{2 x}$ As a result, in order to administer the act effectively it became necessary to permit many taxpayers to report on what was essentially an accrual basis.22 Yet in spite of the obvious disadvantages of the prescribed method of reporting income found in the early legislation, the first income tax statute under the Sixteenth Amendment, the act of I $9 \mathrm{I} 3,^{23}$ also purported to require the taxpayer, corporate as well as individual, to use the cash basis. ${ }^{24}$ In conformity with this general plan taxes were deductible only in the year actually paid. ${ }^{25}$

Increasing pressure for statutory recognition of accounting principles led Congress, in I9r6, to give qualified approval to the use of the actual method of reporting income. However, both the act of I9I6 and the act of $\mathrm{I} 9 \mathrm{I} 7$ continued to employ the language of the earlier statutes when providing for the allowance for taxes; deductible taxes were those "paid within the year." ${ }^{26}$ Since many corporations prior to I9r6 had deducted taxes in the year paid even though their returns were primarily on an accrual basis, it was argued in United States $v$. Anderson ${ }^{27}$ that the congressional approval of the administrative practice did not require a change in the method of deducting taxes-that a taxpayer on the accrual basis was expressly authorized to take the deduction in the year paid instead of the earlier year. ${ }^{28}$ In rejecting this contention the Supreme Court stressed the importance of accurate income reporting. Pointing out that the attempted departure from the accrual basis would clearly distort the tax-

\footnotetext{
${ }^{20}$ In general see McLaren, The Influence of Federal Taxation upon Accountancy, $64 \mathrm{~J}$. of Accountancy 426 (1937); Paton, op. cit. supra note 6, at v.

2I United States v. Anderson, 269 U.S. 422,440 (I927); cf. Reg. 3I, Arts. 4, 5 and T.D. r742, at $\llbracket 77, I_{4}$ Treasury Decisions, Internal Revenue I $_{30}$ (I9I2).

${ }^{22}$ See Aluminum Castings Co. v. Routzahn, 282 U.S. 92, 97 (r930).

${ }^{23} 38$ Stat. 166 (I9I5).

${ }_{24}$ Helvering v. Enright's Estate, 3I2 U.S. 636, 643 (I94I); Magill, Taxable Income I55 (1936); Gore, From Wickersham to Mellon, $42 \mathrm{~J}$. of Accountancy 269 (I926).

${ }^{25} 38$ Stat. 167 , at $\S \amalg(B), r 73$, at $\S \Pi(G)$ (b) (rgr 5 ).

${ }^{26} 39$ Stat. 759 , at $\S 5(\mathrm{a})(4 \mathrm{th}), 769$, at $\S \mathrm{I2}$ (a)(2d) (I9I7); 40 Stat. 330 , at $\S$ I $20 \mathrm{I}(\mathrm{I})(3 \mathrm{~d})$, 335 , at $\S \mathrm{I} 207$ ( $\mathrm{r}$ ) (4th) (I9Ig).

${ }^{27} 269$ U.S. 422 (1926).

${ }^{28}$ See Argument for Appellees, United States v. Anderson, 269 U.S. 422, 427-3x, 433 (I926).
} 
payer's gain for the year, it was declared that, while the deduction section appeared to permit the subtraction of the tax in the year paid, this section should be controlled by the general provisions relating to the method of accounting used to compute taxable income. A taxpayer on the accrual basis could deduct taxes only in the year in which they accrued.

The converse of the Anderson case was before the Supreme Court in United States $v$. Mitchell. ${ }^{29}$ The Revenue Act of IgI8 had changed the language relating to the deduction of taxes from taxes "paid" to taxes "paid or accrued."30 Consequently a taxpayer on the cash basis contended that the statute permitted an election; that irrespective of the method of accounting employed, taxes could be deducted either in the year paid or in the year accrued. Again refusing to permit a deduction inconsistent with the bookkeeping system of the taxpayer, the Court said: "It was not the purpose of the Act to permit gross income actually received to be diminished by taxes or other deductible items disbursed in a later year, even if accrued in a taxable year. It is a reasonable construction of the law that the same method be applied to both sides of the account." ${ }_{3 x}$

Since all subsequent revenue acts have permitted the deduction of taxes in the year "paid or accrued," 32 there has been little occasion to question the rule established by the Anderson and Mitchell decisions. When a tax accrues in one year and is paid in another the propriety of the deduction in a specific period usually depends, of course, upon the method of accounting employed by the taxpayer. With the exception of persons who die during the tax year in question, ${ }^{33}$ taxpayers on the cash basis must deduct taxes in the year paid ${ }^{34}$ while those on an accrual basis must take

$2927 \mathrm{x}$ U.S. 9 (1926).

${ }^{30} 40$ Stat. 1067 , at $\& 214(a)(3)$, 1077, at \& 234(a)(3) (r9rg).

${ }^{3 x}$ United States v. Mitchell, 27 I U.S. 9, I2-I3 (I926).

${ }^{32} 42$ Stat. 239 , at $\$ 2 \mathrm{I} 4(\mathrm{a})(3), 254$, at $\S 234(\mathrm{a})(3)$ ( 2923$) ; 43$ Stat. 270 , at $\S 2 \mathrm{r} 4(\mathrm{a})(3)$, 284 , at $\$ 234(\mathrm{a})(3)$ (I925); 44 Stat. 26 , at $\$ 2 \mathrm{I} 4(\mathrm{a})(3), 42$, at $\$ 234(\mathrm{a})(3)$ (I927); 45 Stat. 799, at $\S 23$ (c) (I929); 47 Stat. I80, at $\S 23$ (c) (I933); 48 Stat. 688, at $\S 23$ (c) (I934); 49 Stat. I659, at $\S 23$ (c) (r936); 52 Stat. 460 , at $\$ 23$ (c) (r938); Int. Rev. Code $\S 23$ (c), 53 Stat. 12 (1939), 26 U.S.C.A. \& 23 (c) (1940).

${ }_{33}$ "In the case of the death of a taxpayer there shall be allowed as deductions and credits for the taxable period in which falls the date of his death, amounts accrued up to the date of his death. ..." Int. Rev. Code $\$ 43,53$ Stat. 24 (I939), 26 U.S.C.A. $\$ 43$ (I940), construed in Roy J. O'Neil, 3 I B.T.A. 727 (1934); cf. Milton D. Eisner, 9 B.T.A. 2 IO (I927). The accrual in such cases was first required by the Revenue Act of 1934,48 Stat. 694, at $\$ 43$ (1934).

34 United States v. Mitchell, 27I U.S. 9 (1926), explaining United States v. Woodward, 256 U.S. 632 (I92x); Edward Hagelin, 37 B.T.A. 8 (I938); Arthur T. Galt, 3I B.T.A. 930 (r934); Benjamin I. Powell, 26 B.T.A. 509 (1932); Ida Wolf Schick, 22 B.T.A. ro67 (r93I); First Nat'l Bank, 22 B.T.A. ro5o (I93); Corinth State Bank, I4 B.T.A. II62 (I929); George C. Beidleman, 7 B.T.A. 899 (1927); Henry Reubel, I B.T.A. 676 (1925); Sidney Weinberg, 
the deduction in the year accrued. ${ }^{35}$

II

In determining the year in which a tax may be deducted it is necessary to establish the system of accounting used by the taxpayer ${ }^{36}$ Ordinarily this problem causes little difficulty since the method employed may be readily classified. However, the solution of the problem is not always apparent. When there is a dispute it is clear that the Government will not be bound by the declaration made by the taxpayer in his return..$^{37}$ The question will be answered through the ascertainment of the dominant plan of the bookkeeping system rather than by the label applied to it by the party in interest..$^{8}$ An occasional departure will not change the general classification which appears appropriate. ${ }^{39}$ Thus minor deviations from either basis will not affect the time for deducting taxes..$^{\circ}$ Somewhat greater uncertainty is caused by taxpayers engaged in and keeping separate

I B.T.A. I78 (ig24); M. W. Alworth, 38 B.T.A. $65^{6}$ (1938). For cases dealing with foreign tax credit see William T. Rich, II B.T.A. I320 (I928); David A. Cunningham, 9 B.T.A. ro5० (1928); Albert D. Hewinson, I B.T.A. I080 (I925); Howard Earl Blood, I3 B.T.A. I49 (I928). Beginning with the Revenue Act of I924, 43 Stat. 279 , at $\$ 22$ (c), 286, at $\$ 238$ (c) (I925), the taxpayer on a cash basis could elect to take the credit in the year the foreign tax accrued. Int. Rev. Code § I3I(d); 53 Stat. 57 (I939), 26 U.S.C.A. \& I3 I(d) (I940); Russell-Miller Milling Co., 27 B.T.A. 405 (1932), aff'd 63 App. D.C. 74, 69 F. (2d) 393 (1934).

35 United States v. Anderson, 269 U.S. 422 (I926); Aluminum Castings Co. v. Routzahn, 282 U.S. 92 (I930); Niles Bement Pond Co. v. United States, 28I U.S. 357 (I930); Elmhirst v. Duggan, I4 F. Supp. 782 (N.Y. I936); Red Wing Potteries, Inc., 43 B.T.A. 84I (r94r); Marguerite Hyde Suffolk \& Berks, 40 B.T.A. II2I (I939); Hecla Mining Co., 35 B.T.A. 454 (I937); American Cigar Co., 2I B.T.A. 464 (r930); Shurtleff Ice Cream Co., I B.T.A. II68 (r925). For cases dealing with foreign tax credits see Hygienic Products Co. v. Com'r, III F. (2d) 330 (C.C.A. 6th I940); Russell-Miller Milling Co. v. Helvering, 63 App. D.C. 74, 69 F. (2d) 393 (1934); Carter, Rice \& Co., 28 B.T.A. 687 (I933), explaining Ruud Mfg. Co. v. Com'r, 45 F. (2d) 63 (C.C.A. 3 d 1930); Mead Cycle Co., то B.T.A. 887 (r928).

${ }^{36}$ Niles Bement Pond Co. v. United States, $28 x$ U.S. 357,360 (1930).

37 Aluminum [Castings Co. v. Routzahn, 282 U.S. 92 (1930). The findings of the commissioner and the Board of Tax Appeals are said to be final. Hygienic Products Co. v. Com'r, II I F. (2d) 330 (C.C.A. 6th I940); see also Niles Bement Pond Co. v. United States, 28I U.S. 357, 360 (r930); United States v. Anderson, 269 U.S. 422, 442 ( 1926 ); cf. United States v. Mitchell, 27 I U.S. 9 , 12 (1926).

${ }^{38}$ See Hygienic Products Co. v. Com'r, IrI F. (2d) 330, 33I (C.C.A. 6th I940).

39 "The return must be filed on the accrual basis . . . . where true income cannot be arrived at on the basis of actual receipts and disbursements." Aluminum Castings Co. v. Routzahn,

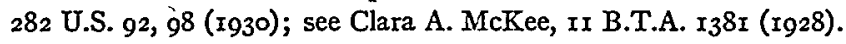

$4^{\circ}$ Cf. Comstock-Castle Stove Co., 4 B.T.A. Ir4 (I926). 
records for their unrelated business activities. ${ }^{4 \pi}$ Where some of the unrelated activities are recorded on the cash basis and others on the accrual basis the taxpayer has been permitted to use both methods of accounting as long as the method used for each business is consistently followed; in conformity with the general rule, taxes are deductible in the year paid or accrued depending upon the method of accounting used for the activity giving rise to the imposition of the tax sought to be deducted. ${ }^{42}$

\section{III}

Where the taxpayer is on a cash basis, the problem of timing is comparatively simple. Since the actual payments may have no relation to the receipts of the taxpayer, there is little conscious effort to match income and expense. Indeed, exactly the opposite is frequently the case; the payment of deductible taxes may be anticipated or deferred solely for the purpose of reducing the amount subject to the federal income tax in a given year. The problem is largely one of determining what constitutes payment within the meaning of the statute; neither the nature of the expenditure nor the purpose for which it is made appears to affect its deductibility.

Generally speaking, payments may be in money, by check, or by the performance of services. ${ }^{43}$ Presumably the payment must be actually received by the tax collector in the year the deduction is claimed; funds sent through the mails in one period and not received until the next should be allowed as a subtraction only in the latter period. ${ }^{44}$ Checks are ordinarily deductible in the year delivered even though not collected until the following year. ${ }^{45}$ But post-dated checks are not treated as ordinary checks which

4I By way of illustration see Old Merchants Nat'l Bank \& Trust Co. v. United States, 36 F. Supp. 96r (Mich. 1939), aff'd per curiam $x \times 7$ F. (2d) 737 (C.C.A. 6th I940).

${ }_{42}$ In Cecil v. Com'r, roo F. (2d) 896 (C.C.A. 4th I939), the taxpayer's "Biltmore Estate" business records were kept on an accrual basis while her more personal records were kept on a cash basis. Consequently she was required to deduct property taxes on the estate in the year of accrual rather than the year of payment. In Bennett Properties Co., 45 B.T.A. II2 (I94I), the taxpayer, except for interest and taxes, used the cash method of accounting; since the books were predominantly on a cash basis it was required to deduct taxes in the year paid instead of the year accrued.

43 Where taxes are paid through services rendered, the taxpayer is not deprived of the deduction, but the amount of it must also be treated as a part of the gross income. Watervliet Paper Co., I6 B.T.A. 604 (r929).

44 Cf. Leach v. Com'r, 50 F. (2d) 37 I (C.C.A. Ist I93I). The rule with respect to taxable income, Avery v. Com'r, 292 U.S. 210 (r934), would seem applicable to this related situation.

45 Com'r v. Bradley, 56 F. (2d) 728 (C.C.A. 6th I932), held that, where a check given in payment of real estate taxes on the day before the taxpayer's death was not presented for payment until after his death, the taxes could be deducted from the gross income of the decedent. The delivery of the check constituted conditional payment; when actually paid the condition subsequent was satisfied and the original payment became absolute. 
are honored in due course..$^{4}$ Similarly, a deposit of bonds to secure the payment of a tax, ${ }^{47}$ money placed "irrevocably" in trust, ${ }^{48}$ or money turned over to an agent of the taxpayer (even though the agent is also the tax collector) ${ }^{49}$ does not constitute payment which will enable a person on the cash basis to deduct the tax in the year in which these transactions take place. Even clearer is the instance where the taxpayer seeks to deduct the tax, not in the year paid, but in the later year in which he repays a loan which had been obtained in order to pay the tax. ${ }^{50}$ It should be noted, however, that it may be possible to claim the deduction even though payment is not actually made to the tax collector. Where there has been a proper tender of the tax in one year and it is rejected, an acceptance in a later year may be deducted in the subsequent period; ${ }^{5 x}$ it is also arguable that the tax, at the election of the payer, may be deducted in the year in which tender was made and improperly refused. ${ }^{22}$

\section{IV}

In contrast with the great bulk of tax payments which offer little occasion for dispute when the taxpayer is on a cash basis, a surprising number of problems have grown out of the provision relating to the deduction of accrued taxes. ${ }^{53}$ Since taxes represent an anomalous type of business expense-a coercive exaction, frequently fluctuating widely in amount and often having little relation to the direct benefits received-it is easy to understand the lack of agreement as to the theoretical accounting basis for their classification as a business expense. But regardless of whether it is believed that taxes are not costs in the strict sense of the word and their

\footnotetext{
${ }^{6}$ If a post-dated check is not payable until its date the instrument should be treated, for tax purposes, as an ordinary promissory note, and, as in the case of such note, the transfer would not constitute payment. Compare the rule in interest cases. Hart v. Com'r, 54 F. (2d) 848 (C.C.A. Ist I932); S. E. Thomason, 33 B.T.A. 576 (I935).

47 Estate of Benjamin Piller, 29 B.T.A. 799 (1934).

$4^{8}$ Edward Hagelin, 37 B.T.A. 8 (1938); Arthur T. Galt, 3 I B.T.A. 930 (1934).

49 Edward Hagelin, 37 B.T.A. 8 (1938).

5o Ida Wolf Schick, 22 B.T.A. Io67 (I93I); William D. Hutchins, I4 B.T.A. 42 I (I928). Similarly the person who makes the loan may not deduct the taxes paid by the borrower. Busch v. Com'r, $5^{\circ}$ F. (2d) 800 (C.C.A. $5^{\text {th }}$ r93 I).

5x Mary Stuart Honeyman, 24 B.T.A. I30 (I93r); Robert B. Honeyman, Jr., 24 B.T.A. 126 (I93I).

52 Some support for this view may be found in Leach v. Com'r, 50 F. (2d) 37 r, 373 (C.C.A. Ist 193I). But see Robert B. Honeyman, Jr., 24 B.T.A. I26, I29 (193I).

53 Unfortunate terminology may account for a part of the difficulty. In general see Magill, op. cit. supra note 8, at I66; Parlin, Accruals to Date of Death for Income Tax Purposes, 87 U. of Pa. L. Rev. 295, 296 (1939); cf. Farrand and Farrand, Treatment of Accrued Items in the Event of the Death of a Taxpayer, I3 So. Calif. L. Rev. 43I, 437-39 (1940).
} 
treatment as such is justified only on the ground of expediency ${ }^{54}$ or that taxes, like other insurance costs, are paid to prevent the loss of property, 55 there is little dispute as to the elementary principles of bookkeeping involved.

Where a business continues over a period of years and there is an attempt to estimate the profits of one of the intermediate years, it is usually necessary to make two kinds of adjustments. Liabilities may be incurred, particularly those near the end of the accounting year, which have not been recorded on the books of the business but which must be considered when calculating the total expenses of the period; thus rent, wages, interest, and similar expenses which are due and payable in a later period must be "accrued" at the end of the year. Conversely, payments may have been made and liabilities recorded which, while incurred during the year, do not relate exclusively to current expenses but which must be deferred to a later accounting period; a five-year insurance policy or a building having an estimated useful life of fifty years illustrates this type of transaction; the expense represented by the extinguishment of the life of the policy or the life of the building relates largely to future years, and it is obviously erroneous to include the total amount in the expenses of the year of purchase. Thus when estimating the annual,success of a business, both accruals and deferments must be considered ${ }^{5}$-and this is as true of taxes as of other expenses. ${ }^{57}$ Tax liability may be incurred even though the amount is not yet due and payable; such taxes must be accrued. Similarly, taxes may be paid in advance for years other than those at hand; the appropriate part of these taxes must be deferred. Unless both adjustments are made, the steps preliminary to the accurate matching of income and expense will be ignored.

It is reasonable to suppose that the provision relating to the deduction of accrued taxes was included in the statute for the purpose of expressly authorizing the taxpayer to make the deduction in a manner which would permit the accurate reflection of current income. As has been seen, even without congressional action and in the face of rather specific language

54 Paton, op. cit. supra note 6, at roI-2.

ss Gilman, Accounting Concepts of Profit 314-I5 (1939); cf. Canning, op. cit. supra note 2, at $37-38$.

${ }^{56}$ In general see Paton and Littleton, op. cit. supra note $r$, at 16 et seq.; Porter and Fiske, Accounting I42, I44-46 (1935).

57 In addition to notes $5^{\circ}$ and 51 supra, see Sanders, Hatfield, and Moore, op. cit. supra note 4, at 75, 82; Lawrence, Cost Accounting I82 (rev. ed. r937); cf. Montgomery, Auditing Theory and Practice 250-52, 298 (6th ed. I940). 
this was the interpretation placed upon the Revenue Act of $1916 . .^{8}$ In the light of subsequent decisions and rulings it is unfortunate that the tax in United States v. Anderson ${ }^{59}$ related exclusively to the accrual of taxes and did not also involve the problem of deferment. In that case the federal munitions $\operatorname{tax},{ }^{60}$ based on I9I6 income, was not assessed or payable until I9I 7 and the taxpayer sought the deduction in the later year. The problem of deferred taxes was not involved and the Court naturally directed its remarks toward the matter at hand. To meet the contention that a tax could not accrue until it was assessed and became due the Court pointed out that both the liability of the taxpayer and the amount of the tax were sufficiently certain to warrant the deduction. "All events may occur which fix the amount of the tax and determine the liability of the taxpayer to pay it. In this respect, for the purpose of accounting and of ascertaining true income for a given accounting period, the munitions tax here in question did not stand on any different footing than other accrued expenses appearing on appellee's books." ${ }^{6 x}$ Inasmuch as the exaction related directly to the income subject to the federal income tax and was for the same period, there was no occasion to discuss either the problem of apportionment or the problem of attaching the tax to related income. The munitions tax, being on income itself, represented the simplest imaginable case of synchronization. ${ }^{62}$ Indeed, virtually the only method of treatment which would fail to result in the matching of income and expense was attempted by the taxpayer when an effort was made to treat the tax solely as a liability; by limiting the question of accrual to the time the obligation matured it was thus possible to argue that the tax did not "accrue" until it became due and payable. However, the Supreme Court was not misled by antiquated notions of balance sheet accounting; ${ }^{63}$ the income statement was the important consideration. But in spite of the fact that accepted accounting practice was clearly approved, the Treasury Department, the Board of Tax Appeals, and many of the federal courts have stubbornly resisted attempts to use orthodox techniques when allocating taxes to the appropriate income years. Much of this resistance, however, may be attributed to the unfortunate manner in which the tax allowance has been treated in the various income tax acts.

$5^{8}$ Pages 445-46 supra. $\quad 59269$ U.S. 422 (I926). $\quad{ }^{60} 39$ Stat. 780 (I9I7).

6x United States v. Anderson, 269 U.S. 422, 44I (r926).

${ }^{62}$ See A.R.M. 26, 2 Cum. Bull. I $_{5}$ (I920), where the Committee on Appeals and Review had anticipated the decision reached by the Supreme Court. But see I.T. 3370, r940-I Cum. Bull. 32.

${ }^{63}$ See Littleton, Accounting Evolution to Igoo, at 356 (I933). 


\section{V}

As has been suggested elsewhere, ${ }^{64}$ a tax should be treated as any other payment or accrual. Those pertaining to the individual's personal expenses should not be allowed as a deduction while those relating to the business affairs of the taxpayer should be governed by the accepted methods of accounting for similar expenditures. Since the deduction would or would not be allowed depending upon whether it constituted a business expense, the technical incidence of the exaction (which is now the decisive question when dealing with non-business taxes) could be ignored. The propriety of the deduction during the current year or its deferment to some later period would then receive some consideration. However, this has not been the method employed by Congress. Following the precedent established in earlier income tax statutes Congress permitted the deduction of "all" taxes when it enacted the Corporate Excise Tax Act of r909..$^{65}$ In view of the crude income concept found in this legislation it was not to be expected that the niceties of accounting would be observed when providing for the deduction of taxes.$^{66}$ The blanket allowance, however, disregarded a limitation customarily imposed upon even the crudest type of cash accounting. When using the cash basis there are many disbursements which are not deductible. Capital charges, such as buildings, equipment, and other permanent investments, are not deductible in the year of purchase. Yet in spite of this recognized qualification, taxes were deductible even though they represented capital outlays. ${ }^{67}$ This basic error was carried over to the later income tax legislation; not only the taxpayers reporting on the cash basis but also the taxpayers reporting on the accrual basis were permitted to deduct many taxes which represented capital charges. Thus incorporation "fees" and other similar taxes ${ }^{68}$ may be deducted in the year the liability for them is incurred; even where such treatment is appropriate there is no requirement that the amount of

64 See the writer's discussion in Deductions from Gross Income: Payments and Accruals Deductible as "Taxes," 3 Wash. and Lee L. Rev. I (r94I).

${ }^{65} 3^{6}$ Stat. $x_{3}$ (rgrr). See pages $444-45$ supra.

66 "Net income shall be ascertained by deducting . . . . (fourth) all sums paid by it within the year for taxes. ...." 36 Stat. II3 (IgII).

${ }^{67}$ Tbid.

68 Clarence Whitman \& Sons, Inc., II B.T.A. Ix92 (I928); I. T. 2625, XI-I Cum. Bull. 25 (I932). If interpreted as a fee instead of a tax the exaction is not deductible since it is a capital expenditure. 3 Paul and Mertens, Law of Federal Income Taxation $\$ \S 23.28,25.06$ (1934). However, "fees" have been treated as taxes and the deduction allowed even though a capital charge. Thus payments made to increase the authorized capital stock of a corporation 
the exaction be spread over the "life" of the $\operatorname{tax}^{69} \mathrm{~A}$ tax need not be deferred..$^{70}$

This flagrant departure from customary accounting practice was the natural result of including within the tax deduction provision both business and non-business taxes. When the Supreme Court in United States v. Woodward ${ }^{7 \mathrm{I}}$ firmly established the principle that taxes may be deducted irrespective of their relation to income ${ }^{72}$ it became necessary to determine the year in which these unrelated taxes could be deducted by a taxpayer on the accrual basis. Although such taxes were not business expenses, they were very real liabilities. Accurate income reporting could not serve as a guide, since a matching of expense and revenue was not involved. Instead it was necessary to accept the balance sheet concept of an accrual, and taxes were considered in terms of liabilities rather than expenses. The problem became one of discovering when the liability for the full amount of the tax "accrued."

Since the Anderson case had rather effectively discouraged the use of the day the tax became "due and payable" 73 as the event determining

may be deducted in full. Clark Thread Co., 28 B.T.A. II 28 (I933); Michigan Central R. Co., 28 B.T.A. 437 (I933); Borg \& Beck Co., 24 B.T.A. 995 (I93I); Holeproof Hosiery Co., II B.T.A. 547 (I928); cf. United Gas Improvement Co. v. Burnet, 64 F. (2d) 957 (C.C.A. 3 d I933); Logan-Gregg Hardware Co., 2 B.T.A. 647 (I925); Emerson Electric Mfg. Co., 3 B.T.A. 932 (1926); Summerill Tubing Co., 36 B.T.A. 347 (I937).

${ }_{69}$ Stamp taxes on bonds issued by a corporation may be deducted in the year "paid or accrued." United States Playing Card Co., I5 B.T.A. 975 (I929); Baltimore \& Ohio R. Co., 30 B.T.A. 194 (I934); see Stires Corp., 28 B.T.A. I (1933); Commercial Investment Trust Corp., 28 B.T.A. I43 (I933); cf. Paton, Accountants' Handbook 890 (2d ed. 1939); Hatfield, Accounting 67 (1927).

70 Taxes on property during construction should be treated as a part of the cost of the property. Paton and Littleton, op. cit. supra note I, at 89; Hatfield, Accounting 7o (1927). However, such taxes may also be deducted in the year "paid or accrued." See Harrisburg Hospital, Inc., I5 B.T.A. Ior4 (1929); Layman, Income Tax Deductions of Federal and Statę Social Security Taxes, I5 Tax Mag. 7I9, 76I (I937).

${ }_{73} 25^{6}$ U.S. 632 (Ig2I). Although this case is no longer authority with respect to the time a tax may be deducted, note 34 supra, and the specific tax in question has been subsequently disallowed, op. cit. supra note 64 , at $3 \mathrm{I}$, the principle that taxes may be deducted even though not related to income does not appear to have been disturbed.

72 In computing taxable income the federal estate tax was held to be deductible from the income of the decedent's estate.

${ }^{73}$ A number of earlier cases had indicated that the tax "accrued" when it became "due and payable," e.g., United States v. Woodward, 256 U.S. 632, 635 (I921); L. S. Ayers \& Co., I B.T.A. II35 (I925); Norwich \& Worcester R. Co., 2 B.T.A. 215 (I925); Atlantic Coast Line R. Co., 2 B.T.A. 892 (I925); Bartles-Scott Oil Co., 2 B.T.A. I6 (I925); Russell Milling Co., I B.T.A. I94 (I924); Jamestown Worsted Mills, I B.T.A. 659 (I925); see May, Taxable Income and Accounting Bases for Determining It, $40 \mathrm{~J}$. of Accountancy 248, 264 (I925). 
when a tax "accrued," it became necessary to select some other stagè in the collection of revenue as the date which determined the deductibility of the exaction. ${ }^{74}$ Consequently the day of "assessment," 75 the date the "liability" of the taxpayer was determined, ${ }^{76}$ and the day the "lien" attached to the property ${ }^{77}$ were frequently selected as the proper time to accrue various taxes; the last mentioned date was easily the favorite when property taxes were considered..$^{8}$ After selecting a date for the "accrual" of a non-business tax it was, perhaps, too much to expect a busy administrative or judicial body to reexamine the question of accrual when confronted with a business tax. In any event, considerations which led to the selection of a specific day for the accrual of a personal tax were also accepted as determinative when considering the proper time for deducting business taxes. And since a non-business tax could be deducted in a year which bore no relation to the income-producing activities of the taxpayer it automatically followed that business taxes could be deducted in a year other than that in which the related income was earned. The problem of matching could be ignored. If Congress saw no objection to the deduction of a personal tax which did not relate to income and thus permitted

74 The many steps in the collection of a general property tax make the choice a difficult one. Seventeen are listed for Ohio. See Broh-Kahn, Accrual of General Property Tax in Ohio, I5 U. of Cin. L. Rev. 359, 368-69 (I94I).

75 I. T. 3326 , I939-2 Cum. Bull. I57. Frequently the "assessment" and some other event will have occurred within the period in question and both will be emphasized. John $\mathrm{H}$. Hord, 33 B.T.A. 342 (1935), rev'd 95 F. (2d) I79 (C.C.A. 6th I938); First Bond \& Mortgage Co., 27 B.T.A. 43 ० (I932); Leamington Hotel Co., 26 B.T.A. I004 (x932); cf. G.C.M. 22454, 1940-2 Cum. Bull. 2ro; G.C.M. 22636, I941-I Cum. Bull. 352, where the bureau has reluctantly modified its position, but only to the extent required by controlling decisions.

$7^{76}$ For references to the "liability of the taxpayer" as the time for accrual see Burchell v. Helvering, ir 5 F. (2d) 68I (C.C.A. 2d I940); Walsh-McGuire Co. v. Com'r, 97 F. (2d) 983 (C.C.A. 6th I938); Union Bleachery v. Com'r, 97 F. (2d) 226 (C.C.A. 4th I938); Ed. Schuster \& Co., Inc. v. Williams, 283 Fed. Ií5 (C.C.A. 7 th I922); S. E. \& M. E. Bernheimer Co., 4 I B.T.A. 249 (I940), aff'd per curiam I2I F. (2d) 454 (C.C.A. 2d I94r); Edward C. Kohlsaat, 40 B.T.A. 528 (r939); Gatens Investment Co., 36 B.T.A. 309 (I937); California Sanitary Co., Itd., 32 B.T.A. I22 (1935); Great Northern R. Co., 30 B.T.A. 69I (I934); Arcade Dept. Store, Inc., I8 B.T.A. $x x_{72}$ (I930); Crown Willamette Paper Co., I4 B.T.A. I33 (I928); H. H. Brown Co., 8 B.T.A. II2 (1927); Klauber Embroidery Works, II B.T.A. 779 (r928). In American Liberty Oil Co., 43 B.T.A. 76 (I940), Texas Coca-Cola Bottling Co., 30 B.T.A. 738 (1934), and Grand Hotel Co., 2 I B.T.A. 890 (I930), both the "personal liability" and the "lien" events were stressed.

77 See Com'r v. Plestcheeff, I0o F. (2d) 62 (C.C.A. 9th I938); Lifson v. Com'r, 98 F. (2d) 508 (C.C.A. 8th' 1938), cert. den. 305 U.S. 662 (I939); T. H. Banfield, 42 B.T.A. 769 (r940); Milton H. Friend, 40 B.T.A. 768 (I939); Estate of Charles Schimmel, 39 B.T.A. 989 (I939), aff'd Ir 4 F. (2d) 554 (C.C.A. 8th I940); Cloquet Co-operative Society, 2I B.T.A. 744 (I93O); note 76 supra.

${ }^{8}$ Pages $45^{6}$ et seq. infra. 
an understatement of taxable income and a permanent loss of federal revenue there was even less objection to the deduction in a single year of a business tax which should be allocated over a number of years-the temporary understatement of income would be (presumably) compensated by an overstatement of income in subsequent years.

Although the unnecessary generosity of Congress with respect to personal taxes discouraged administrative or judicial attempts to require the matching of business taxes and taxable income, it was possible to limit the scope of this broad deduction and somewhat limit the extent of the distortion caused by it. In Nat'l Bank of Commerce v. Allen ${ }^{79}$ the deduction by a corporation of a tax collected from it but laid upon its stockholders was disallowed. Inasmuch as the corporation made no attempt to collect the payment from its stockholders the amount in controversy was, in effect, a dividend and properly eliminated as an expense; as was said by the district court, if the result were otherwise the taxpayer would not "correctly state its net income." Uno Unfortunately, however, later courts apparently lost sight of this excellent reason for the earlier decision; it was not repeated in similar cases. Without attempting to explain the rationale of their decisions the courts were content merely to state their conclusions: the taxpayer could deduct only its "own" taxes. ${ }^{8 x}$ Consequently in many cases no effort was made to determine whether the disallowance of "another's" tax did not also constitute the disallowance of a proper business expense. Although the effect of these corporationstockholder tax cases was nullified when Congress later permitted the deduction, ${ }^{82}$ the general rule, strongly supported by the decisions involving non-business taxes, ${ }^{83}$ continued to flourish. When one taxpayer paid the personal taxes of another it was difficult to employ the reasoning of the Nat'l Bank of Commerce decision, since it could hardly be argued that the deduction of another's tax was to be denied because the deduction distorted the income of the person making the payment, an argument which applied with equal force to the allowable deduction of one's "own" per-

7921 I Fed. 743 (D.C. Mo. I914).

80 Ibid., at 747; cf. Eliot Nat'l Bank v. Gill, 2ro Fed. 933,936 (D.C. Mass. 1913), aff'd 2r8 Fed. 600 (C.C.A. Ist I9I4).

8I Eliot Nat'l Bank v. Gill, 218 Fed. 6co (C.C.A. Ist I9I4); First Nat'l Bank v. McNeel, 238 Fed. 559 (C.C.A. $5^{\text {th }}$ I917); Porter v. United States, 27 F. (2d) 882 (C.C.A. gth I928), cert. dismissed 279 U.S. 875 (I929); Northern Trust Co. v. McCoach, 215 Fed. 991 (D.C. Pa. I914); cf. United States v. Central Nat'l Bank, 24 Fed. 577, 578 (D.C. N.Y. I885).

${ }^{82} 42$ Stat. 239-40, 254-55 (I923); see'Int. Rev. Code $\S \S 23(d), 203(a)(5), 53$ Stat. I2, 72 (1939), 26 U.S.C.A. $\$ \S 23$ (d), 203 (a)(5) (I940).

$8_{3}$ See op. cit. supra note 64 , at 6 et seq. (I94I). 
sonal taxes. ${ }^{84}$ Consequently it soon became established that a tax paid for another could not be deducted as $a \operatorname{tax}^{85}$ even though the payment represented a business expense. Furthermore, the allowance for taxes, as has been seen, ${ }^{86}$ was also restricted by the requirement that the exaction could be deducted as a tax only in the year in which the tax was "paid or accrued." ${ }^{17}$ With the development of these two limitations the foundation was laid for the many cases involving the deduction of taxes upon property which was transferred during a given year.

In breaking away from the income concept when dealing with taxes it became easy to ignore the usual accounting conventions pertaining to it. Where the taxpayer purchases property burdened with unpaid taxes it is obvious that the taxes for past years do not represent current expenses; they should be capitalized. ${ }^{88}$ The cases so holding ${ }^{89}$ reach a correct result, but this reason for the decision is not always given. ${ }^{90}$ Too frequently the

${ }^{84}$ Some of the difficulties occasioned by this "rule" are found in Borland v. Com'r, I23 F. (2d) 358 (C.C.A. $7^{\text {th }}$ r 94 I).

85 Although not deductible as a tax, such payments frequently were deductible as a business expense. Thus lessees who agreed to pay taxes on property leased could deduct the tax as rent if the property was used in the taxpayer's trade or business. John D. Fackler, 39 B.T.A. 395 (1939); Denholm \& McKay Co., 39 B.T.A. 767 (1939). But where the business "voluntarily" pays the tax it is not deductible even as a business expense. Robinson v. Com'r, 53 F. (2d) 8ro (C.C.A. 8th I93I); Nat'l Piano Mfg. Co. v. Burnet, 60 App. D.C. I6o, 5o F. (2d) 310 (I93I); I. T. 3382, r940-I Cum. Bull. I2.

${ }^{86}$ Pages 446-47 supra.

${ }^{87}$ For an unnecessarily harsh application of the annual accrual requirement see Swain \& Myers, Inc., 42 B.T.A. 360 (1940), where the taxpayer was required to include the amount of the local sales tax in its gross income but was not permitted to deduct the tax on those credit sales which had not yet been collected.

${ }^{88}$ See Joell Co., 4I B.T.A. 825, 827 (I940); California Sanitary Co., Ltd., 32 B.T.A. I22, I25 (1935).

${ }^{89}$ Falk Corp. v. Com'r, 60 F. (2d) 204 (C.C.A. 7th I932); Merchants Bank Bldg. Co. v. Helvering, 84 F. (2d) 478 (C.C.A. 8th I936); Joell Co., 4I B.T.A. 825 (I940); Midtown Tower, Inc., 40 B.T.A. II6 (r939); Luke W. McCrory, 25 B.T.A. 994 (1932); Grand Hotel Co., 2I B.T.A. 890 (I930). In such cases I) the vendor on an accrual basis would deduct the tax each year as it accrued, T. H. Symington \& Son, Inc., 35 B.T.A. 7II (I937); see First Bond \& Mortgage Co., 27 B.T.A. 430,432 (I932); 2) the vendor on a cash basis would deduct the $\operatorname{tax}$ in the year paid by the vendee and treat the payment as an addition to the amount received from the sale for the purpose of determining gain or loss, Norman Cooledge, 40 B.T.A. I325 (r939), vacating 40 B.T.A. I Io (I939); see Mim. 5200, I94x-3 C.C.H. Fed. Tax Serv. $\llbracket 6424$. But see Nunnally Investment Co. v. United States, 36 F. Supp. 332 (Ct. Cl. I94I). In addition, if a wasting asset is concerned, the vendee is permitted to amortize the cost over the life of the asset when it is used for business purposes. Midtown Tower, Inc., 40 B.T.A. II6 (I939).

${ }^{90}$ See Shearer v. Com'r, 48 F. (2d) 552, 555 (C.C.A. 2 d I93I) ("the form of the statute must control"); Helvering v. Missouri State Life Ins. Co., 78 F. (2d) 778 (C.C.A. 8th 1934) (no discussion); Merchants Bank Bldg. Co. v. Helvering, 84 F. (2d) 478, 48 I (C.C.A. 8th 1936) ("a deduction may only be taken by that taxpayer whose property gives rise to the deduction'). 
opinion contains merely the statement that one taxpayer may not deduct another's tax.91 It is this unnecessarily broad generalization which causes so much difficulty when dealing with current taxes. The early cases considering the deductibility of taxes assessed on property transferred during the year did not depart from orthodox practice even though they were later cited as a justification for the distortion of the taxpayer's annual income. In John Hancock Mutual Life Ins. Co. ${ }^{92}$ property was purchased in September, the taxes for the year having "accrued" on April I, and the commissioner permitted the deduction of that part of the tax allocable to the time the property was held by the purchaser but not that part allocable to the period prior to purchase; in sustaining the action of the commissioner, the Board of Tax Appeals followed recognized accounting procedure. In Shearer v. Com'r $r^{93}$ the federal motor tax imposed upon dealers was "passed on" to the purchaser who sought to deduct it from his gross income; in disallowing the deduction the decision appears satisfactory, from an accounting point of view, since the tax should be treated as a part of the cost of the automobile and, if deducted at all, it should be recovered as depreciation over the life of the asset. Again, in Falk Corp. v. Com'r, ${ }^{94}$ where one corporation acquired the assets of another and agreed, as a part of the purchase price, to pay the state income tax of the latter, the requirement that the tax be capitalized, rather than deducted either in the year paid or in the year contractual liability for it was incurred, clearly conformed to customary usage; the payment was a part of the cost of the asset and it should not be deducted in its entirety in a single year.

However, the increasing emphasis upon the question of the technical imposition of the tax rather than the accounting character of the exaction ultimately led to decisions which disregarded the latter and more relevant problem. In Arcade Dept. Store, Inc.,95 a corporation was permitted to deduct the full amount of an annual tax on assets owned by its predecessor partnership, when the corporation had acquired the property before the day the taxes were said to have "accrued." Since the corporation paid its "own" tax the Board of Tax Appeals saw no objection to the deduction. Other board decisions during this period reflected this same approach; persons acquiring property before the day of "accrual" were entitled to the full amount of the year's tax ${ }^{96}$ but a purchaser after this day was

${ }^{9 x}$ See Merchants Bank Bldg. Co. v. Helvering, 84 F. (2d) 478, 48r (C.C.A. 8th I936); Luke W. McCrory, 25 B.T.A. 994, rorr (1932); First Bond \& Mortgage Co., 27 B.T.A. 430, 432 (1932).

${ }^{92}$ ro B.T.A. 736 (1928).

${ }^{93} 48$ F. (2d) 552 (C.C.A. 2d 193I).

9460 F. (2d) 204 (C.C.A. $7^{\text {th }}$ 1932).

${ }^{96}$ Theodore Plestcheef, 35 B.T.A. 508 (I937). 95 I8 B.T.A. II72 (I930). 
denied any deduction for the year. ${ }^{97}$ Where a business organization acquired, for example, an apartment building subject to an annual tax of $\$ 50,000$ there would be no deduction for the year of acquisition if the tax "accrued" January $r$ 'even though the property was purchased the following day,$^{98}$ while a taxpayer in another jurisdiction could take the full deduction if the tax "accrued" December $3 x$ even though the property was acquired the preceding day. .9

Because of the evident distortion of the tax base resulting from this arbitrary treatment of an expense it is unfortunate that the federal courts were not more critical when confronted with the problem. ${ }^{\text {100 }}$ The view of the Board of Tax Appeals was, ostensibly at least, accepted in Helvering $v$. Missouri State Life Ins. Co ${ }^{\text {Ior }}$ when a purchaser was again denied the deduction of current taxes which had become a lien upon the property prior to acquisition. Although this case purported to accept the board rule, it may be explained on the ground that the taxpayer was an insurance company subject to special income tax provisions enacted because of the tremendous difficulties encountered when attempting to estimate the annual income of such organizations; ${ }^{\mathbf{1 0 2}}$ since these provisions departed in many respects from orthodox income concepts ${ }^{\mathrm{T03}}$ it is arguable that life insurance company cases should not be considered persuasive when considering the problem of the ordinary taxpayer. Yet in spite of the anomalous character

97 Leamington Hotel Co., 26 B.T.A. 1004 (1932); First Bond \& Mortgage Co., 27 B.T.A. 430 (I932); Alden Anderson, 27 B.T.A. 980 (I933); Texas Coca-Cola Bottling Co., 30 B.T.A. 736 (I934); California Sanitary Co., Ltd., 32 B.T.A. I22 (I935).

${ }_{98}$ Consider, for example, the taxes in American Liberty Oil Co., 43 B.T.A. $76,8 x$ (x940), and Texas Coca-Cola Bottling Co., 30 B.T.A. 736 (r934); I. T. 3388, I940-2 Cum. Bull. 66; I. T. 34r4, I940-2 Cum. Bull. 7o; I. T. 3435, 1940-2 Cum. Bull. 73; I. T. 3506, 194x-3 C.C.H. Fed. Tax Serv. $\lceil 6519$.

99 Johnson County Realty Co., 44 B.T.A. I2I (I94I).

${ }^{100}$ From both a practical and a theoretical point of view the result seems unsatisfactory. Aside from the question of accurate net income, the emphasis upon the technical imposition of the tax ignores not only customary practice but also economic principles. Many taxes on property are "capitalized" and the original owner at the time the tax was imposed bears the full burden even though the purchaser pays taxes subsequent to acquisition. In a very real sense, unless the rates are increased the purchaser never pays his "own" tax. See Twentieth Century Fund, Facing the Tax Problem 238 et seq. (1937); Kendrick, Incidence and Effects of Taxation, 27 Am. Econ. Rev. 725, 730 (r937); Einaudi, Capitalization and Amortization of Taxes, 3 Encyc. Soc. Sci. 2xI (r935); Seligman, Shifting and Incidence of Taxation I 74 et seq., 22I et seq. ( $5^{\text {th }}$ ed. r927).

${ }^{\text {rot }} 7^{8} \mathrm{~F}$. (2d) 778 (C.C.A. 8th I934).

s02 In general, see 4 Paul and Mertens, Law of Federal Income Taxation $\S 36.01$ (I934).

io3 By way of illustration see Com'r v. Lafayette Life Ins. Co., 67 F. (2d) 209 (C.C.A. 7 th I933) (taxes on life insurance building not deductible since taxpayer failed to include rental value in gross income). 
of life insurance taxation the Missouri State Life Ins. Co. decision was cited, in Merchants Bank Bldg. Co. v. Helvering, ${ }^{\text {104 }}$ as authority for the proposition that grantees could not deduct as an expense taxes which had become a lien before transfer. Since the tax in the latter case was for the year prior to purchase the deduction was properly denied and the Falk Corp. decision, quoted in the opinion, was ample authority for the point actually decided: back taxes should be capitalized.

In Walsh-McGuire Co. v. Com'r ${ }^{\text {ros }}$ the doctrine of the Board of Tax Appeals was accepted by a court which, three months earlier, had permitted the beneficiary of a trust to deduct current property taxes assessed against the trustees but paid by the beneficiary after the termination of the trust. ${ }^{106}$ Limiting the earlier case to its facts, the court held that a corporation which was organized on April I6 and which immediately afterward acquired certain real estate could not deduct any part of the current taxes assessed on it because the tax "accrued" on April r2. In spite of the fact that the annual charge was clearly allocable, in part, to the time the taxpayer owned the property, Judge Florence Allen said that "since none of the payment was made in liquidation of petitioner's liability, a proportionate deduction of that part of the tax allocable to the period .... instead of fairly reflecting petitioner's income; would have resulted in a distortion thereof." "ro7

Other federal courts also followed the rule laid down by the Board of Tax Appeals. The taxpayer in Lifson v. Com' $r^{\mathrm{x} 08}$ was denied the deduction of a current tax when property was purchased after the tax had become a lien on the real estate and was allowed the full deduction in Com'r v. Plestcheeff ${ }^{\mathrm{rog}}$ when the property was purchased before the current tax became a lien on the property. The taxpayers in the last two cases were on a cash basis and the great inaccuracies of this method of accounting may serve to mitigate the criticism of the result. But in Walsh-McGuire Co. v. Com' $r^{\text {rro }}$ the taxpayer was on an accrual basis and the result would clearly seem to violate the principle laid down by the Supreme Court in United

${ }_{104} 84$ F. (2d) 478 (C.C.A. 8 th 1936 ).

${ }^{\text {ros }} 97$ F. (2d) 983 (C.C.A. 6 th I938); cf. Broh-Kahn, op. cit. supra note 74 , at $385-88,395-$ 96.

${ }^{106}$ Hord v. Com'r, 95 F. (2d) I79 (C.C.A. 6th 1938); John Edgerly Morrell, 43 B.T.A. $65 \mathrm{I}$ (I94).

${ }_{107}$ Walsh-McGuire Co. v. Com'r, 97 F. (2d) 983, 985 (C.C.A. 6th I938). The Hord case was distinguished on the ground that the taxpayer was the beneficial owner of the property "at the time of the incidence of the tax."

${ }^{108} 98$ F. (2d) 508 (C.C.A. 8th I938), cert. den. 305 U.S. 662 (1939).

${ }^{109}$ I00 F. (2d) 62 (C.C.A. 9th $\mathrm{r} 938$ ).

${ }^{220} 97$ F. (2d) 983 (C.C.A. 6 th 1938 ). 
States v. Anderson ${ }^{\text {II }}$ when it declared that the deduction of a tax did not depend upon its accrual in a "technical legal sense" but in an "economic and bookkeeping sense." Technically the tax had accrued before the purchase of the property, but in an accounting sense the tax should have been spread over the entire tax year; otherwise the revenues received from the use of the property by the taxpayer for the remainder of the year would not bear the burden of the tax properly allocable to this activity.

However, in spite of numerous analogies ${ }^{\text {Ir2 }}$ leading to the conclusion that annual taxes should be treated, for income tax purposes, as relating to a single day, there is a definite trend away from this view and toward that indicated by the Anderson decision. In Com'r v. Coward ${ }^{\mathrm{nx} 3}$ the taxpayer who purchased real estate on January 8 was permitted to deduct all but $8 / 3^{6} 5$ of the tax assessed for the year of purchase. Rejecting the rule of thumb provided by the "tax day" concept, the Circuit Court of Appeals for the Third Circuit observed that the taxpayer's income was largely derived from real estate and with the exception of $8 / 365$ of the tax "one cannot imagine a clearer case for the deduction." ${ }_{\mathrm{Ir} 4}$ Thus the requirement of accurate reflection of annual income, previously rejected, ${ }^{115}$ was again recognized. In Carondelet Bldg. Co., Inc. v. Fontenot ${ }^{116}$ the taxpayer purchased property on May Io, capitalized that part of the year's tax allocable to the time prior to purchase, deducted that part allocable to the period May ro to September 3o, the end of the taxpayer's fiscal year, and deferred to the following fiscal year the balance. In approving this practice it was said that the corporation "knew the rents which were accruing each month could not be treated as net, but ought to bear the monthly

${ }^{\text {IIx }}{ }_{269}$ U.S. 422, 44I (I926). See Ellis, Deductions for Accrued Taxes, I4 Tax Mag. I97 (1936).

11 Supposed administrative convenience has led to the use of a day certain for the purpose of determining the taxability of persons or property. Thus the existence of property, its situs, or its ownership on a specific day will frequently determine the person subject to the tax and whether or not given property will be taxed during the year. The tax day is also important when considering the question of exemptions. See 2 Cooley, Taxation $\$ \$ 546$, 7 I2 (4th ed. I924). In the administration of trusts the problem of allocating tax expenditures to principal and income has been solved by reference to the time the tax attached. The same has been true with respect to the problem of apportioning tax expenses between the life tenant and remainderman or reversioner. However, in both types of situations the rule of apportionment usually prevails. 3 Simes, Future Interests 28-29 (1936); 2 Scott, Trusts 1326-27 (1939); see I Rest., Property §I 29(g) (1936); Rest., Trusts § 237(a) (1935).

${ }^{2 \times 3}$ I Io F. (2d) 725 (C.C.A. 3d I940). $\quad$ Ir4 Ibid., at 728-29.

Irs Helvering v. Missouri State Life Ins. Co., 78 F. (2d) 778 (C.C.A. 8th I934); WalshMcGuire Co. v. Com'r, 97 F. (2d) 983 (C.C.A. 6 th I938); First Bond \& Mortgage Co., 27 B.T.A. 430 (1932).

${ }^{216}$ III F. (2d) 267 (C.C.A. 5th 5940$)$. 
pro rata of the annual taxes to fairly reflect net income." The commissioner "did not disapprove of the taxpayer's method of accounting because not fairly reflecting income for the period, but solely because he concluded that as a matter of law 'real and personal property taxes in Louisiana accrue for federal income tax purposes on Jan. I each year.' We think there is no such rule of law. . . . L Looking rather to a just accounting that will truly reflect net income, we think that the prorated deduction as claimed ought to have been maintained." ${ }^{\mathrm{Ix} 7}$ In Com'r v. Rust's Estate ${ }^{\mathrm{Ir} 8}$ the purchaser of property was again permitted to deduct that part of the annual real estate tax allocable to the time the property was held by the purchaser. "Taxes upon real estate constitute an ever recurring burden; and when, as in this case, the property is held as an investment, they are perforce treated as a current expense to be offset against current income. ... The apportionment of the tax was clearly correct. . . . The opposing theory advanced by the Commissioner .... does violence to the purpose of the income tax statutes that items of income shall be accounted for in annual periods. Clearly this purpose will not be served if the constantly recurring burden of the tax is refused recognition as an item of current expense and is placed in the category of a capital expense to be reckoned with under the income tax statutes only in the event of sale at some future date."'rrg

In the Coward decision emphasis was laid on the fact that the tax in question had not become a lien upon the property at the time of transfer, that the local statute did not impose a personal liability upon the owner, and that the purchaser had not contracted to pay the tax in question. ${ }^{\text {.20 }}$ Consequently it was possible to distinguish the federal cases which had accepted the "tax day" idea. ${ }^{\text {x2x }}$ In the Carondelet Bldg. Co. and the Rust's Estate opinions the absence of personal liability for taxes and the fact that a lien had not attached at the time of the purchase were also emphasized. ${ }^{122}$ However, in the latter decision the parties had agreed to apportion the $\operatorname{tax}^{123}$ and the court also questioned, but refused to decide, whether the personal liability of the vendor or a lien upon the property

117 Ibid., at 269 .

${ }^{218}$ II6 F. (2d) 636 (C.C.A. 4th 1940). Parker, J., dissented.

rig Ibid., at 638-39.

${ }^{220}$ Com'r v. Coward, xio F. (2d) 725, 727 (C.C.A. 3 d I940).

${ }^{22}$ Ibid., at 727 n. 10.

${ }^{222}$ Carondelet Bldg. Co. v. Fontenot, III F. (2d) 267,268 (C.C.A. 5th I940); Com'r v.

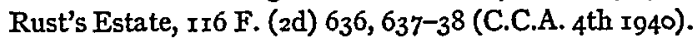

${ }^{223}$ Com'r. v. Rust's Estate, II6 F. (2d) 636, 638 (C.C.A. 4th I940). 
at the time of sale should affect its decision. ${ }^{124}$ It was not until Supplee v. Magruder $^{\text {I25 }}$ that a federal court permitted the purchaser to deduct his share of a local tax on property purchased during the year even though the purchaser was under a contractual obligation to pay the tax, the tax had become a lien upon the property before purchase, and, apparently, the tax was a personal liability of the vendor. Pointing out that there would have been no question as to the propriety of the deduction if the statute had not specifically provided for the deduction of taxes since the $\operatorname{tax}$ in question was necessary to the taxpayer's real estate business and thus was a business expense, ${ }^{226}$ the "tax day" treatment was rejected and the local custom ${ }^{\text {I27 }}$ of apportioning taxes accepted as controlling. The problem of taxes in arrears was distinguished ${ }^{228}$ and that of current expenses emphasized. "The general purpose of the income tax is to find and tax the true net income as defined in the statute. This is accomplished only when current taxes and similar items are deducted from the current income. When an income taxpayer purchases investment property he is chargeable only with the income subsequently accruing from the property, and current charges against it are properly deductible to ascertain net income. If the current income is adjusted to the date of transfer, similarly the current charges against the income should be likewise adjusted." 229 On appeal the lower court was affirmed in a per curiam opinion on the basis of the Rust's Estate decision..$^{\mathbf{1 3 0}}$

In spite of these recent cases, however, the decisions with respect to 'transfers and related problems are by no means unanimous. In Burchell v. Helvering ${ }^{\mathrm{I3}}$ the attention of the court was focused exclusively upon the problem of ascertaining, under local law, the exact day upon which a tax "accrued." The Board of Tax Appeals has also taken varying positions. In T. H. Banfield ${ }^{132}$ the taxpayer who purchased property on March 4 was

${ }^{2} 4$ Ibid., at 640 .

${ }^{225} 36$ F. Supp. 722 (MId. I94I), aff'd per curiam I23 F. (2d) 399 (C.C.A. 4th I94I), cert. granted to U.S.L. Week 3283 (1942).

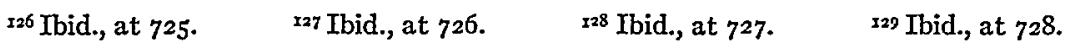

${ }^{3}{ }^{30}$ Magruder v. Supplee, r23 F. (2d) 399 (C.C.A. 4th I94I). "Judge Parker dissents on the ground that the taxes paid, being a lien on the land and a personal liability of the vendor at the time of the conveyance to the taxpayer, were not deductible by the latter from income, for the reasons set forth in the dissenting opinion in the Rust case." Ibid., at 400.

${ }^{{ }^{3} 3 \mathrm{r}}{ }_{115}$ F. (2d) 68x (C.C.A. 2d r940). The testator died November 12, 1934, and his executor, pursuant to $\S 43$ of the Revenue Act of 1934,48 Stat. 694 (r934), attempted to deduct the current annual property tax from the testator's income. The deduction was denied because the court, while confessing to "considerable uncertainty," was of the opinion that the tax "accrued" in December.

${ }_{332} 42$ B.T.A. 769 (1940); see M. P. Klyce, 4I B.T.A. 194 (1940). 
not permitted a tax deduction for that year since the lien attached on March I. Yet in New Orleans. Cold Storage \& Warehouse Co., Ltd. ${ }^{x 33}$ the taxpayer changing its accounting year was permitted to defer Io/ I2 of an annual tax which had "accrued" in the preceding fiscal year. And in Godfrey L. Cabot, Inc. ${ }^{\mathrm{x} 34}$ the taxpayer was permitted to prorate the annual tax on a monthly basis and thus spread the tax over the appropriate part of successive fiscal years. Again in S.E. E M. E. Bernheimer Co ${ }^{\mathrm{x} 35}$ a proration was allowed; the taxpayer changed its accounting year from a calendar year to a fiscal year ending September 30 and was permitted to deduct 9/12 of the annual tax in that year. ${ }^{\mathrm{x} 36}$ This case was affirmed in a memorandum opinion ${ }^{\mathrm{r} 37}$ citing United States $v$. Anderson ${ }^{\mathrm{r} 38}$ and Carondelet Bldg. Co., Inc. v. Fontenot, ${ }^{139}$ by the same court which decided the Burchell case. However, in Crown Zellerbach Corp. ${ }^{14^{\circ}}$ the board reverted again to the "tax day" technique when it denied the taxpayers the right to prorate annual taxes to the proper fiscal years in conformity with their usual accounting practice. While the New Orleans, Cabot, and Bernheimer cases involved the accounting methods of the same taxpayer and did not present the supposed difficulty found in those situations where one person paid another's tax, subsequent decisions make it clear that the board has not rejected the "tax day" concept of a tax accrual. ${ }^{1{ }^{11}}$ In Citizens Hotel Co. ${ }^{x_{42}}$ the taxpayer was denied the right to allocate on a monthly basis the tax for the year; although it had merely changed its accounting year, the tax for those months which fell in the new fiscal period was not deductible

${ }_{233} 40$ B.T.A. I2I (I939). The taxpayer changed its method of reporting from a fiscal year ending February 28-29 to a calendar year. Thus the period in question was March I to December $3 \mathrm{r}$. Although the tax became a "liability" on January $\mathrm{I}$, the board recognized that "the pertinent question here is whether the method of bookkeeping employed by the petitioner correctly reflected the income of the petitioner. . . . We think it did." Ibid., at I23, I26.

${ }^{234} 40$ B.T.A. 366 '(I939). The taxpayer's books were based on a fiscal year ending September 30 , and state taxes assessed each calendar year were allocated on a monthly basis.

${ }^{135} 4$ I B.T.A. 249 (I940).

${ }^{136}$ "This action we believe to have been proper and to have been in accord with the principles of accrual accountancy." Ibid., at 254 .

${ }^{337}$ Helvering v. Bernheimer Co., I2r F. (2d) 454 (C.C.A. $2 d$ x94I).

${ }^{23^{8}} 269$ U.S. 422 (I926). $\quad{ }_{239}$ III F. (2d) 267 (C.C.A. 5 th I940).

${ }^{{ }^{10}} 43$ B.T.A. 54I (I94I).

${ }^{241}$ Note the attitude reflected in G.C.M. 22113, r940-I Cum. Bull. I23. With reference to the Coward case it was said: "the application of that decision will be confined to cases dealing with New Jersey real property taxes." Compare the statement in G.C.M. 226r3, I941-r Cum. Bull. 30r: "the decision in the Rust case will not be given general application but will be applied only in cases involving District of Columbia real property taxes."

${ }^{142} 44$ B.T.A. 560 (194I). 
because it was a "personal" liability which had become a "lien" on the property during the first of the accounting years in question. Thus the judicial limitation upon the deduction of taxes which had been invoked to prevent the further distortion of income where one taxpayer attempted to deduct the tax paid for another ${ }^{\mathrm{I} 43}$ was applied in a manner which defeated, in part, its original purpose.

The present attitude of the Board of Tax Appeals was stated in Pyramid Metals Co. ${ }^{x 4}$ The taxpayer purchasing property on August I was not permitted to deduct an aliquot part of the year's tax because it was said that the tax "accrued" on April I. Commenting upon the contrary doctrine represented by the Supplee decision, the board said: "The long established rule based on sound reason should not be plowed under at this late date." Whatever may have been the "sound reason" for its holding, it admittedly was not sound accounting practice. Section 43 of the Internal Revenue Code, requiring the accurate reporting of income, was said to be inapplicable to "minor items" like those before the board for decision.

\section{VI}

When reporting on an accrual basis the taxpayer may invoke the antiquated balance sheet concept of accounting and deduct taxes in the year in which the liability was incurred instead of using the more accurate income statement concept and deduct the tax in the year in which the related income was earned. However, the taxpayer is permitted, in many cases, to employ the latter concept if he so elects.

Where a tax is imposed as the result of an act over which the taxpayer has some control, it is apparent that the tax should be considered a part of the cost of the transaction. A duty on imports or an excise tax on the manufacture of some product may properly be considered a part of the cost of the article imported or manufactured. ${ }^{x 5}$ A matching of revenue and expense would require the deduction of the tax as a part of the cost of goods at the time they are sold; where commodities are imported or

${ }^{2} 43$ See page 455 supra.

${ }^{144} 44$ B.T.A. I087 (I94I). In American Liberty Oil Co., 43 B.T.A. 76 (1940), the Carondelet case was distinguished; there being, under the local law, both a personal liability and a lien before the transfer, the deduction for current taxes was denied. In Johnson County Realty Co., 44 B.T.A. I2I (x94I), and Lowell H. Chamberlain, 43 B.T.A. 259 (I94I), property was acquired after "the" day and the full deduction was allowed. As a result of conflicting decisions it has recently been observed that when property is sold between tax dates "it's anybody's guess now whether the taxes are deductible by the seller, the buyer, both, or neither, in whole or in part." Seidman, Salient Features of Federal Income Taxes-r941 Style, 73 J. of Accountancy 37, 40 (I942).

445 Porter and Fiske, Accounting 380 (x935). 
manufactured in one year and sold in another the tax on them is a significant item of expense in the later year only. Although it is said that "the question is not free from doubt," the taxpayer may take the tax deduction as a part of the cost of goods sold in the year of sale rather than in the year the legal obligation to the taxing authority arose. ${ }^{146}$ As long as there is no duplication of the deduction this treatment is sound. ${ }^{x 7}$ It should be noted, however, that the taxpayer is not required to take the deduction in the later year; the deduction may be taken in the year in which the liability arose-and this even though the preferable method was followed when keeping books for ordinary accounting purposes. ${ }^{148}$. It is evident that when dealing with taxes of this character the latter treatment may be only slightly less inaccurate than the cash disbursements method of reporting taxable income.

Where the tax is a recurrent charge it becomes necessary to relate this expense to specific activity. The levy, assessment, and collection of the tax may extend over a period longer than a year. ${ }^{49}$ These recurrent impositions take place every twelve months, but the amount of the tax may

${ }^{{ }^{46} 6}$ LeBolt \& Co. v. United States, 67 Ct. Cl. 422, 428 (r929); cf. Elmira Arms Co., 7 B.T.A. 703 (I927); O. D. I37, I Cum. Bull. II2 (I9I9); Mim. 5200, I94I-3 C.C.H. Fed. Tax Serv. T) 6424 .

${ }^{347}$ An analogous problem is presented when property is held for future sale. The capitalization of current taxes in such cases is generally approved by accountants. See Paton, op. cit. supra note 6, at 257; Montgomery, Auditing Theory and Practice 616 (4th ed. 1927); cf. Westerfield v. Rafferty, 4 F. (2d) 590 (D.C. N.Y. I925). However, in spite of $\S 202$ (b) of the Revenue Acts of 1924,43 Stat. 255 (r925), and of 1926,44 Stat. 11 (I927), and $\&$ I I (a) of the Revenue Act of 1928 , 45 Stat. 8I5 (I929), which provided for expenditures "properly chargeable to capital account," according to statements found in the Report of the Committee on Ways and Means, H.R. Rep. x79, 68th Cong. Ist Sess., at I2 (1924), and Reg. 69, Art. $156 \mathrm{I}$ ( 1926 ), the capitalization of such taxes was disallowed in Central Real Estate Co. v. Com'r, 47 F. (2d) 1036 (C.C.A. 5th I93r). Section II3(b)(I) of the Revenue Act of I932, 47 Stat. 201 ( 1933 ), expressly corrected this error. Int. Rev. Code $\S$ II3 $_{3}$ (b)(I)(A), 53 Stat. 20I (I939), 26 U.S.C.A. § $\mathrm{rI}_{3}$ (b)(I)(A) (I940); Patrick McGovern, Inc., 40 B.T.A. 706 (I939); I. T. 3434 , I940-2 Cum. Bull. 90; Reg. I03, at $\$$ I9.42-4 (I940), for the treatment of taxes in long term contract situations.

${ }^{2} 8$ Pathe Exchange, Inc. v. Com'r, 77 F. (2d) 306 (C.C.A. 2d I935), explaining LeBolt v. United States, 67 Ct. Cl. 422 (I929); Reg. I03, at $\S$ I9.23 (c)-2; Layman, op. cit. supra note 7o, at $76 \mathrm{r}$; I. T. 3389, 1940-2 Cum. Bull. 67. If the taxpayer may repudiate his own method of accounting it is to be expected that the Government in other types of cases will exercise the same privilege. Compare Atlantic Coast Line Co., 2 B.T.A. 892 (rg25), and First Nat'l Bank, 22 B.T.A. ro50 (I93I), with Armstrong Cork Co., 24 B.T.A. I (I93I), New Orleans Cold Storage \& Warehouse Co., Ltd., 40 B.T.A. I2I (I939), and Godfrey L. Cabot, Inc., 40 B.T.A. 366 (1939).

${ }^{249}$ See the taxes considered in Helvering v. Schimmel, 114 F. (2d) 554 (C.C.A. 8th I940); Cecil v. Com'r, 100 F. (2d) 896 (C.C.A. $4^{\text {th }}$ r939); Cloquet Co-operative Society, 2r B.T.A. 744 (1930); Universal Winding Co., 39 B.T.A. 962 (x939); Columbian Carbon Co., 25 B.T.A. $45^{6}$ (1932). 
be determined by events occurring over several years. ${ }^{x 50}$ For example, a corporate privilege tax may be measured by the income of the preceding year or by the average income of a number of years and it may not be payable until a subsequent year. Where there is no liability for the tax unless the corporation is doing business during a part of a given year this condition would ordinarily indicate the specific twelve months for which the tax was laid..5I All of the income-producing activity of the taxpayer during this period should bear its proper part of the burden. Similarly the general property tax of a manufacturing concern is often distributed with the other overhead of the business and becomes a part of the cost of goods manufactured ${ }^{\mathrm{x} 52}$ and, as in the case of taxes more directly related to specific activity, is not actually deducted from gross income until these goods are sold. Thus I94I taxes, although apparently deducted in full in that year, would actually be reduced by the amount that such taxes were included in ending inventories and this amount so absorbed would be deducted in some later year; in effect, a part of the tax deduction is deferred, a deferment in accord with good accounting practice and permitted under the present legislation. Presumably, however, the taxpayer may elect to deduct the tax in full in the year liability for it was incurred instead of deferring the part allocable to the business of later years. ${ }^{x 3}$ In view of the difficulties involved in distributing general taxes where the business is engaged in a variety of activities this non-deferment is less objectionable than the same treatment of taxes which represent capital expenditures or those which clearly relate to a specific product. But even here, when the taxpayer has followed the more acceptable practice for usual accounting purposes, it is questionable policy to permit a different treatment for the purpose of computing taxable net income.

Greater difficulties are encountered when the taxpayer and the taxing authorities are on different accounting years. ${ }^{154}$ When, for example, the local government lays a tax on a calendar year basis and the taxpayer re-

${ }^{150}$ E.g., Art Metal Construction Co. v. United States, 17 F. Supp. 854 (Ct. Cl. 1937); Ameri ${ }^{-}$ can Laundry Mąchinery Co., 32 B.T.A. 793 (I935); Stuart W. Webb, 5 B.T.A. 366 (r926). Note I49 supra.

${ }^{155}$ Kossar \& Co., I6 B.T.A. 952 (I929); Petaluma \& Santa Rosa R. Co., II B.T.A. 54I (1928); cf. Stuart W. Webb, 5 B.T.A. 366 (I926).

${ }^{\text {r5z }}$ Paton, op. cit. supra note 6, at 102; Van Sickel, Cost Accounting 259, 26I (x938); Sanders, Cost Accounting for Control ${ }^{6} 6$ (I934).

${ }^{153}$ Compare the similar treatment of import duties, note 148 supra.

${ }^{154}$ See S. E. \& M. E. Bernheimer Co., 4I B.T.A. 249 (I940), aff'd per curiam I2I F. (2d) 454 (C.C.A. 2d I94I); Godfrey L. Cabot, Inc., 40 B.T.A. 366 (I939); New Orleans Cold Storage \& Warehouse Co., Ltd., 40 B.T.A. I2I (r939); H. H. Brown Co., 8 B.T.A. II2 (I927); Russell Milling Co., I B.T.A. I94 (I924). 
ports income on a fiscal year basis ${ }^{155}$ the accepted accounting practice is to apportion the local tax to the respective parts of both fiscal years falling within the calendar year in question. ${ }^{156}$ A taxpayer having a fiscal year ending April 30 would allocate one-third of the I94r tax to the fiscal year ending April 30, I942. A "tax day" designated for administrative convenience in collecting the recurring exaction would not, in this connection, appear significant. Strangely enough, however, annual taxes, instead of being considered an expense allocable to the activity of the business conducted throughout the year, have been treated as if they were significant only during one day; taxes "accrued" on one certain day and that day was required to bear the full burden of the annual tax. ${ }^{\text {ist }}$ Where the amount of the tax remains the same from year to year this makes little difference, but where there is a substantial fluctuation in the amount of the tax the distortion resulting from this unrealistic treatment is apparent. Greater distortion may result when the taxing authority changes the "accrual" date of the tax ${ }^{\mathrm{I5} 8}$ or when the taxpayer changes his period of accounting ${ }^{759}$ the change may result either in the loss of a deduction for a year or in the allowance of two years' taxes in a single fiscal year. ${ }^{160}$ An even more extreme case is found in those situations where the taxpayer either sells or purchases income producing property during the tax year. It is here that the "tax day" idea causes the most obvious departure from customary practice; regardless of the length of time the property is held during the year the full amount of the tax may be deducted by the person owning the property on the day the tax "accrued." The fortuitous wording of a local tax statute has been permitted to override the congressional mandate that the method of accounting shall "clearly reflect the income" 6 (6x of the taxpayer. Attention has been directed toward the intricacies of local tax law ${ }^{162}$ rather than toward the problem of ascertaining annual

${ }_{255}$ Com'r v. Patrick Cudahy Family Co., I02 F. (2d) 930 (C.C.A. 7th 1939).

${ }^{x 56}$ Cochran, Accounting for Property Taxes, I6 Tax Mag. 656 (I938); Lawrence, Cost Accounting $181-82$ (rev. ed. I937); Burton, Introduction to Cost Accounting I50-5I (I936); Willcox, Cost Accounting I47-49 (1934); Armstrong, Essentials of Industrial Costing $7 \mathrm{I}$ (I92 I); Accounting Research Bulletin No. Io, Real and Personal Property Taxes, 72 J. of Accountancy 55 (I942).

257 For example, Mim. 5200, at $\$ 6$, 1941-3 C.C.H. Fed. Tax Serv. 76424 .

r58 Nat'l Casket Co., 29 B.T.A. I39 (r933); I. T. 3374, I940-I Cum. Bull. 34 -

${ }_{259}$ Notes $\mathrm{r}_{33}, \mathrm{r} 35, \mathrm{x}_{3} 6$, and $\mathrm{r}_{42}$ supra; $\mathrm{cf}$. Union Bleachery v. Com'r, 97 F. (2d) 226 (C.C.A. $4_{\text {th }}$ 938) (one corporation succeeded another).

${ }^{160}$ G.C.M. 8553 , IX-2 Cum. Bull. Io9 (I930); I. T. 3370, I940-I Cum. Bull. 32; note $5_{58}$ supra.

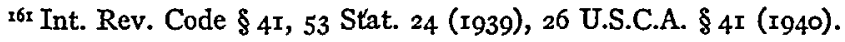

${ }^{162}$ Paul, Selected Studies in Federal Taxation 24 (2d series I938). 
gain. ${ }^{6_{3}}$ As a result of the present emphasis upon local law it has been impossible to achieve any degree of uniformity. The time and manner in which each particular type of tax is assessed, levied, and collected may vary widely, not only from state to state, but also among taxing authorities within a state. With more than I50,000 taxing units in the United States ${ }^{164}$ laying an increasing variety of exactions, the bulk of administrative detail pertaining to the specific day each tax is to be deducted may easily become as unmanageable as it is unnecessary. To a person on an accrual basis the fiscal year of the taxing authority should furnish a sufficient guide to the solution of the problem of attaching annual taxes to business activity. ${ }^{165}$

If "taxes" are eliminated as a separate deduction, there would be no occasion to continue the arbitrary restrictions which have failed to perform that function for which, perhaps, they were originally intended-the accurate reflection of income. Even though this objective may be attained through decisions like those represented by Supplee v. Magruder, ${ }^{\mathrm{I} 66}$ the legislative action would be more than justified. Both the elimination of non-business taxes as a deduction and the deferment of taxes which represent capital expenditures are necessary if annual gain is to be computed in a reasonably accurate fashion. ${ }^{67}$ This increase in accuracy will not only provide a more equitable income tax base but will also yield an appreciable increase in revenue. ${ }^{168}$ While both results are of consequence during ordinary years, they become immeasurably more important during a time of soaring rates and unprecedented demands for revenue.

${ }^{{ }^{6} 3}$ Helvering v. Schimmel, II4 F. (2d) 554 (C.C.A. 8th I940), amply illustrates the effect of considering these conflicting guides. The statement of the general principle was excellent, but its application was far from satisfactory. Compare United States Trust Co., I3 B.T.A. Io74 (x928), and O.D. $37 x, 2$ Cum. Bull. II2 (I920), with A.R.R. II53, I-2 Cum. Bull. 92 (I922).

I64 U.S. Taxes, I6 Fortune No. 6, at Io7 (I937).

${ }^{165}$ Thayer, Taxes as Deferred Debits, I8 J. of Accountancy II4, II7 (I9I4).

${ }^{166}{ }_{36}$ F. Supp. 722 (Md. I94I), aff'd ${ }^{2} 23$ F. (2d) 399 (C.C.A. 4th I94I), cert. granted Io U.S.L. Week 3283 (1942).

${ }^{267}$ Montgomery, Income Tax Procedure 352 (rgI 7). See also Paul, The Emergency Job of Federal Taxation, 27 Cornell L.Q. 3, I9 (I94I); Seligman, The Income Tax 684 (2d ed. I914).

${ }^{268}$ See op. cit. supra note 64 , at 3 n. Io. 